УДК 631.472

\title{
К ОЦЕНКЕ ГУМУСНОГО СОСТОЯНИЯ И ФЕРМЕНТАТИВНОЙ АКТИВНОСТИ ПОЧВ ДАЛЬНЕВОСТОЧНОГО МОРСКОГО ЗАПОВЕДНИКА
}

\author{
Жарикова Е. А., Пуртова Л. Н., Попова А. Д. \\ Федеральный научный ичентр биоразнообразия наземной биоты Восточной Азии \\ ДВО РАН, г. Владивосток \\ E-mail: ejarikova@mail.ru
}

\begin{abstract}
Показатели гумусного состояния и каталазной активности определены в почвах Дальневосточного морского заповедника. Среднее содержание гумуса выявлено в темногумусовой почве, сформированной на погребенном буроземе и буроземе темногумусовом. Распределение гумуса по профилю оценивается как постепенно убывающее, его запасы в 20-сантиметровом слое характеризуются как очень высокие и высокие. Варьирование типового состав гумуса по профилю и степень гумификации в исследуемых почвах отличаются. В составе гуминовых кислот преобладают «свободные» фракции, их доля достигает высоких и очень высоких значений. Поверхностным горизонтам почв свойственна бедная и очень бедная обогащенность каталазой. Морфологический облик профиля и параметры гумусового состояния темногумусовой почвы, сформированной на погребенном буроземе, и бурозема темногумусового Дальневосточного морского заповедника подтверждают полученные ранее сведения об изменении климата и трансгрессии океана в юго-западной части тихоокеанского побережья региона в голоцене.
\end{abstract}

Ключевые слова: почвы, гумусное состояние, каталазная активность, изменение климата.

DOI: 10.34078/1814-0998-2020-4-82-89

\section{ВВЕДЕНИЕ}

Образование островов зал. Петра Великого относится к позднему неогену (плиоцен). В четвертичный период очертания береговой линии Приморья и его климат неоднократно менялись (от умеренно теплого до умеренно холодного и даже холодного). На морских террасах выявлены следы трех осцилляций уровня моря, последняя трансгрессия океана произошла в голоцене, и ее последствия хорошо выражены в виде комплекса высоких и низких морских террас (Короткий, 1994; Короткий и др., 2005). В настоящее время на большей части территории заповедника превалирует холмисто-увалистый и останцовопедиментный рельеф с абсолютными высотами до 150 м, водоразделы преимущественно плосковершинны, склоны пологие и средней крутизны (Белянин, 2015).

Климат побережья и островов характеризуется повышенной по сравнению с материком влажностью воздуха, обильными туманами и сильными ветрами, которые являются одной из причин отсутствия лесной растительности на мористых восточных и юго-восточных склонах. Сумма ак-

() Жарикова Е. А., Пуртова Л. Н., Попова А. Д., 2020 тивных температур на островах варьирует от $2200^{\circ} \mathrm{C}$ на наветренных, подверженных постоянному выносу морских ветров берегах и склонах возвышенностей до 2600 и $2900^{\circ} \mathrm{C}$ в подветренных бухтах и распадках (Ластовецкий, Якунин, 1981; Научно-прикладной..., 1988).

Растительный покров территории неоднороден, в нем соседствуют широколиственные леса (липово-кленово-дубовые, ясеневобархатово-смородиновые, барбарисо-мелкоплодниково-рододендровые, ясенево-аралиево-рододендровые фитоценозы), полынно-злаковые группировки, элементы ксерофитно-полукустарниковых и петрофильно-травянистых сообществ, разнотравно-злаковые и остепненные луга, сорно-разнотравная растительность (Чубарь, 2005).

Почвенно-географическое районирование России относит территорию юго-западного Приморья к хвойно-широколиственной зоне бурых лесных почв Восточной буроземной лесной области (Добровольский, Урусевская, 2004). На довольно узких береговых полосах материковых побережий и небольших островах зал. Петра Великого сочетание своеобразных климатических условий (длительный безморозный период, по- 
вышенное количество осадков) и предсубтропической северо-корейской и маньчжурской флоры способствует большому разнообразию почв на относительно небольшой площади. Поскольку почвы формируются в условиях, которые заметно отличаются от условий внутриконтинентальных территорий, им присущи особые специфические черты морфологии и состава (Зонн, 1976; Ивлев, 1982; Добровольский, 1991; Пшеничников, Пшеничникова, 2014, 2019; Костенков, Жарикова, 2018; Жарикова, 2019). При явном доминировании типичных буроземов здесь выявлены и другие типы почв, в том числе почвы с темногумусовым горизонтом, относящиеся к разным классификационным группам (отдел структурнометаморфических почв - буроземы темногумусовые и отдел органо-аккумулятивных почв - темногумусовые почвы), а также почвы со сложным профилем, содержащим погребенные гумусовые горизонты, унаследованные от более ранних стадий почвообразования.

Согласно концепции памяти почв система гумусовых веществ хорошо отражает особенности состава компонентов природной среды, при которой почва формировалась (Дергачева, 2008). Состав, строение и свойства гуминовых кислот, их соотношение с другими компонентами гумуса и гумусового профиля имеют свою значимость при реконструкции природной среды и ее эволюции. Кроме того, гумусовые вещества являются основой формирования морфологического облика почв, влияют на их основные свойства (Дергачева, 2018). В гумусовых профилях отчетливо «записаны» последовательные смены условий почвообразования в течение всего периода образования почвенного тела, при этом система гумусовых веществ обладает относительно стабильными характеристиками в геологических масштабах времени (Дергачева, 1984, 2008).

Все биологические процессы, связанные с превращением вещества и энергии в почве (в том числе и гумификация), протекают при обязательном участии ферментов. Относительный уровень ферментативной активности почв диагностирует интенсивность и направленность почвообразовательных процессов. Помимо этого ферменты осуществляют функциональные связи между различными компонентами экосистемы, поэтому их активность отражает состояние почвенного микробного сообщества и является относительно стабильным параметром среди показателей, характеризующих биологическую активность почв (Звягинцев, 1978; Yang et al., 2008). Каталаза, один из ферментов класса оксидоредуктаз, играет ведущую роль в протекании окислительно-восстановительных реакций в почве и участвует в процессах синтеза гумусовых веществ. Ее характерной особенностью является активность в очень широком диапазоне почвенной кислотности (pH 4-10) (Schonbaum, 1976).

К настоящему времени установлено влияние химического состава атмосферных осадков, процессов прибойного и капельноимпульверизационного увлажнения и особенностей растительного покрова на пространственно-сезонную динамику щелочнокислотного состояния и состава почвенных растворов, трансформацию органического вещества (включая пирогенную) и некоторые особенности гумусообразования в почвах япономорского побережья (Коваль, 1987; Пшеничников, Пшеничникова, 2002, 2005, 2014, 2015; Елпатьевский, 2004; Костенков, Клышевская, 2014; Латышева, 2019). Но оценка параметров гумусного состояния и ферментативной активности почв Дальневосточного морского заповедника до настоящего времени не проводилась, поэтому она и является основной целью данной работы.

\section{МЕТОДИКА ИССЛЕДОВАНИЯ И ФАКТИЧЕСКИЙ МАТЕРИАЛ}

Объектом исследований выбраны темногумусовая почва, развитая на погребенном буроземе, и бурозем темногумусовый. Содержание гумуса определено по методу Тюрина, его фракционногрупповой состав - по Пономаревой-Плотниковой (Орлов, Гришина, 1981). Оценка гумусного состояния проведена по градациям Д. С. Орлова с соавторами (2004). Каталазная активность исследована газометрическим методом по Галстяну (Хазиев, 2005), ее оценка выполнена по градациям Д. Г. Звягинцева (1978). Кислотность (рН водный) почв определяли потенциометрически, грануломерический состав пирофосфатным методом (Агрохимические..., 1975).

Разрез 8. Заложен на шлейфе юго-западного склона в бухте Западная о. Фуругельма (Хасанский район Приморского края), уклон 4-5, высота около 10 м, расстояние до уреза воды около 70 м. Растительность сорно-разнотравная, проективное покрытие высокое. На поверхности опад листьев и трав мощностью до 4 см.

AU 0-22 (37) см. Влажноватый, темно-серый с бурым оттенком, песок, рыхлый, бесструктурный, в слое 0-10 см корни встречаются очень обильно, глубже - обильно, отдельные корни достигают диаметра 5 мм, присутствуют кусочки бурого угля (непирогенные), переход постепенный, граница языковатая, с гумусовыми затеками.

AUC 22-38 см. Влажный, серый с коричневым оттенком, с затеками гумуса, мелкий песок, рыхлый, бесструктурный, содержит отдельные корни, угли (следы пирогенеза), переход постепенный, граница ровная. 
[AY] 38-66 см. Влажный, темно-серый c бурым оттенком, опесчаненный суглинок, комковато-порошистый, рыхлый, содержит тонкие корни диаметром до 2 мм, обильнее, чем в горизонте АC, присутствуют следы пирогенеза, фрагменты керамики, переход постепенный, граница языковатая с затеками гумуса.

[BM] 66-85 см. Сырой, буро-коричневый, опесчаненный легкий суглинок, комковатоглыбистый, уплотнен, с глубины 75 см сочится вода, содержит отдельные тонкие корни, переход постепенный, граница ровная.

[BMC] 85-100 см. Влажный, буроватокоричневый, опесчаненный средний суглинок, комковато-глыбистый, плотный.

Почва - темногумусовая на погребенном буроземе. Профиль сложный, содержит погребенные горизонты. Наличие в профиле второго гумусового горизонта, литологически отличного от соседних слоев, является результатом прерывания почвообразования в результате активного седиментогенеза (Турсина, 2012). Поскольку верхняя почва достаточно хорошо развита, то основное название дается по результатам диагностики верхней части профиля (Полевой..., 2008). Кусочки бурого угля в поверхностном слое являются артефактом хозяйственной деятельности (до образования заповедника на острове находились объекты Министерства обороны СССР). Угли и фрагменты керамики в погребенном слое [AY] свидетельствуют о наличии на данной территории поселений древних людей (Гарковик, 2004).

Разрез В5. Заложен в нижней трети северного склона горы Туманная (п-ов Гамова), между бухтами Спасения и Астафьева (Хасанский район
Приморского края) в охранной зоне заповедника. Высота 94 м, уклон примерно 10. Редколесье с кустарниково-разнотравной растительностью. На поверхности опад листьев и трав мощностью до $3 \mathrm{~cm}$.

AU 0-28 см. Влажный, темно-серый, почти черный, среднесуглинистый, комковатозернистый, очень рыхлый, содержит обильно корни диаметром до 2 см, встречаются дождевые черви, переход заметный, граница ровная.

AUB 28-39 см. Влажный, темно-серый с бурым оттенком, среднесуглинистый, комковатый со склонностью структурных отдельностей к горизонтальной делимости, рыхлый, встречаются тонкие корни, дождевые черви, переход резкий, граница ровная.

ВМ 39-56 см. Влажный, бурый с серым оттенком, среднесуглинистый, комковатый, уплотнен, содержит отдельные корни, слабокаменистый, переход постепенный, граница ровная.

ВМС 56-68 см. Влажный, бурый (светлее предыдущего), среднесуглинистый, комковатый, уплотнен, сильнокаменистый.

Почва - бурозем темногумусовый.

\section{РЕЗУЛЬТАТЫ И ИХ ОБСУЖДЕНИЕ}

Величина $\mathrm{pH}$ водной вытяжки по всему профилю темногумусовой почвы, сформированной на погребенном буроземе, указывает на слабокислую реакцию среды (см. таблицу). По гранулометрическому составу профиль резко дифференцирован, верхние горизонты песчаные, погребенные слои - суглинистые, в них заметно выше доля тонких частиц (см. рисунок). Содержание гумуса оценивается как среднее при средне-

Таблица. Некоторые показатели гумусного состояния почв Дальневосточного морского заповедника Table. Some indicators of humus status in soils of the Far Eastern Marine Reserve

\begin{tabular}{|c|c|c|c|c|c|c|c|c|c|}
\hline \multirow[t]{2}{*}{ Горизонт } & \multirow[t]{2}{*}{$\begin{array}{c}\text { Глубина, } \\
\text { см }\end{array}$} & \multirow[t]{2}{*}{$\begin{array}{l}\mathrm{pH} \\
\text { вод. }\end{array}$} & \multirow[t]{2}{*}{$\begin{array}{c}\text { Гумус, } \\
\%\end{array}$} & \multirow{2}{*}{$\begin{array}{c}\text { Запасы } \\
\text { гумуса } \\
\text { в слое } \\
0-20 \text { см, } \\
\text { т/га }\end{array}$} & \multicolumn{3}{|c|}{$\begin{array}{c}\text { Доля фракции } \\
\text { гуминовых кислот, } \\
\text { в \% от их суммы }\end{array}$} & \multirow[t]{2}{*}{ Сгк/Сфк } & \multirow[t]{2}{*}{$\Phi К-1 \mathrm{a}^{* * * *}$} \\
\hline & & & & & $1 *$ & $2 * *$ & $3 * * *$ & & \\
\hline \multicolumn{10}{|c|}{ Разрез 8. Темногумусовая на погребенном буроземе темногумусовом } \\
\hline $\mathrm{AU}$ & $0-22$ & 5.9 & 7.65 & 212.7 & 51.5 & 48.4 & 0.01 & 1.11 & 1.5 \\
\hline AUC & $22-38$ & 6.2 & 4.14 & Не опр. & 63.5 & 36.4 & 0.01 & 0.63 & 1.7 \\
\hline [AU] & $38-66$ & 6.1 & 1.34 & Не опр. & 86.2 & 13.7 & 0.01 & 1.75 & 7.6 \\
\hline$[\mathrm{BM}]$ & $66-85$ & 6.1 & 0.88 & Не опр. & 93.7 & 6.2 & 0.01 & 0.96 & 11.7 \\
\hline \multicolumn{10}{|c|}{ Разрез В5. Бурозем темногумусовый } \\
\hline $\mathrm{AU}$ & $0-28$ & 6.3 & 7.24 & 152.0 & 75.0 & 11.3 & 13.7 & 1.18 & 5.7 \\
\hline $\mathrm{AB}$ & $28-39$ & 4.9 & 3.96 & Не опр. & 84.9 & 3.5 & 11.6 & 0.85 & 12.3 \\
\hline $\mathrm{BM}$ & $39-56$ & 5.2 & 1.79 & Не опр. & 59.2 & 40.7 & 0.01 & 0.96 & 19.2 \\
\hline $\mathrm{BMC}$ & $56-65$ & 5.2 & 1.74 & Не опр. & 70.6 & 29.3 & 0.01 & 0.54 & 20.8 \\
\hline
\end{tabular}

*Доля 1-й фракции гуминовых кислот, «свободных » и связанных с полуторными оксидами.

**Доля 2-й фракции гуминовых кислот, связанных с $\mathrm{Ca}^{2+}$.

***Доля 3-й фракции гуминовых кислот, прочно связанных с минеральной основой почв.

****Содержание фракции ФК-1а (Сфк-1а), \% от Собщ. 

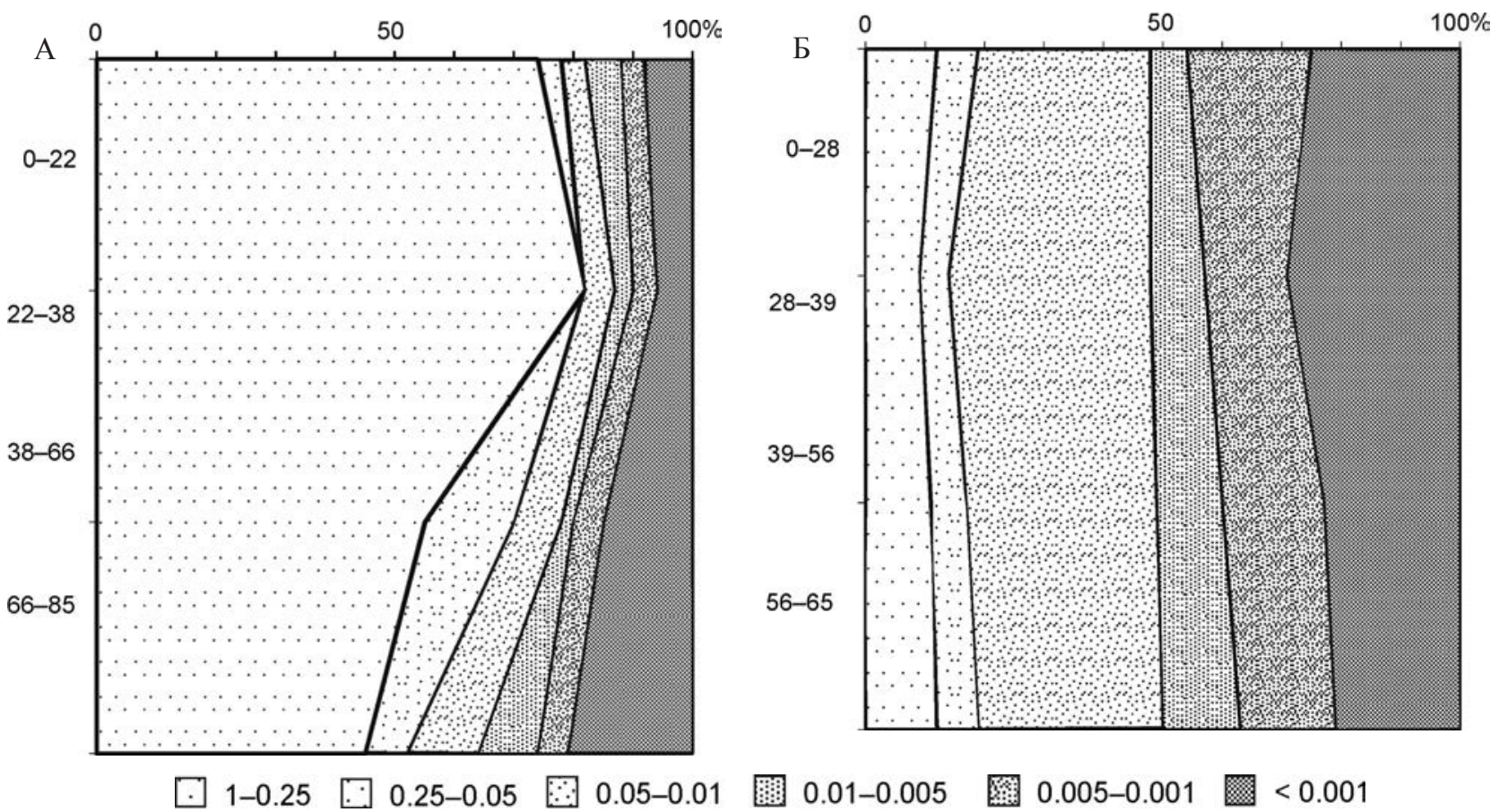

Рисунок. Гранулометрический состав почв: А - темногумусовая почва, сформированная на погребенном буроземе, Б - бурозем темногумусовый

Figure. Texture of soils: A - dark humus soil formed on buried burozem, Б - dark humus burozem

типичной мощности горизонта AU. Внутрипрофильное распределение гумуса постепенно убывающее. Запасы гумуса, из-за повышенных значений плотности сложения почв в слое

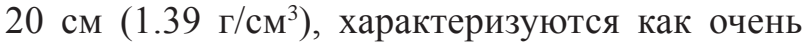
высокие. Среди гуминовых кислот преобладают «свободные» и связанные с полуторными оксидами фракции ГК (фракция 1) при явно выраженной тенденции увеличения их количества с глубиной, чему способствует сочетание низкой адсорбционной способности почв и промывного характера водного режима. В морфологическом облике профиля это хорошо выражено языковатой формой перехода между горизонтами с многочисленными затеками гумуса. Содержание гуминовых кислот, связанных с кальцием (фракция 2), убывает вниз по профилю. В горизонте AU их количество среднее, в слое AUC - низкое, а в погребенных горизонтах [AY] и [BM] снижается от очень низких до крайне низких значений. При этом доля фракции гуминовых кислот, прочно связанных с минеральной основой почв (фракция 3 ), оценивается как низкая по всей почвенной толще. Тип гумуса вниз по профилю меняется от фульватно-гуматного в горизонте AU до фульватного в AUC. В погребенном горизонте [AY] он гуматный, в погребенном слое [ВМ] вследствие значительного возрастания содержания агрессивной фракции фульвокислот (ФК-1а) гуматно-фульватный.

Можно предположить, что различия в показателях Сгк/Сфк погребенных и современных го- ризонтов обусловлены различиями в климатических условиях их формирования. Согласно концепции гумусовой памяти почв более высокие показатели соотношения Сгк/Сфк в глубоких слоях характерны для формирования почв в более теплых и менее гумидных условиях, тогда как похолодание и возрастание влажности способствуют увеличению в составе гумуса содержания фульвокислот и снижению соотношения Сгк/Сфк (Дергачева, 2018).

Самые высокие значения степени гумификации выявлены в погребенных слоях, что служит еще одним свидетельством наличия более теплого и сухого климата в момент формирования этих палеогоризонтов почв. Степень гумификации в современных поверхностных слоях слабая, что указывает на заторможенность процессов разложения органического вещества почвенной микрофлорой, полученные низкие показатели ферментативной активности подтверждают это утверждение. Уровень каталазной активности в горизонте AU равен $2.4 \mathrm{O}_{2} \mathrm{~cm}^{3} / 1$ г почвы за 1 мин, что характеризует обогащенность почв каталазой как бедную. С глубиной показатели каталазной активности резко уменьшаются и варьируют в пределах 0.7-0.5 $\mathrm{O}_{2} \mathrm{~cm}^{3} / 1$ г почвы за 1 мин, что позволяет оценить обогащенность почв каталазой как очень бедную.

В буроземе темногумусовом слабокислая реакция среды свойственна только поверхностному слою, в остальных горизонтах она кислая. Почвы тяжелосуглинистые, в средней части профиля увеличено количество фракции тонкой пыли 
(см. рисунок). Содержание гумуса с глубиной снижается от средних до низких и малых значений (см. таблицу), его распределение по профилю характеризуется как постепенно убывающее. Мощность поверхностного горизонта $\mathrm{AU}$ среднетипичная. Запасы гумуса в слое 0-20 см оцениваются как высокие. Буроземы темногумусовые выделяются большим содержанием гуминовых кислот (Сгк/Сфк 1.18) в поверхностном горизонте. Тип гумуса меняется с глубиной с фульватно-гуматного в верхнем слое на гуматно-фульватный (в середине профиля) и фульватный (в нижних слоях). Среди гуминовых кислот (ГК) доминируют «свободные» фракции гуминовых кислот и фракции, связанные с полуторными оксидами, их доля достигает высоких и очень высоких значений. Количество ГК, связанных с кальцием, лежит в диапазоне от очень низкого до крайне низкого, за исключением метаморфического горизонта ВM, в котором оно среднее. По содержанию гуминовых кислот, прочно связанных с минеральной основой почв, профиль бурозема темногумусового отчетливо дифференцирован, в поверхностных горизонтах их доля достигает средних значений, с глубиной резко убывает. При этом в составе гумусовых кислот значительно возрастает содержание агрессивной фракции фульвокислот (ФК-1а) (от средних до высоких показателей). Степень гумификации в основном средняя, наибольшие значения присущи метаморфическому слою ВМ.

В буроземе темногумусовом обогащенность каталазой оценивается как бедная и очень бедная. Каталазная активность меняется по профилю и составляет в горизонте $\mathrm{AU}-2.2 \mathrm{~cm}^{3}$ $\mathrm{O}_{2} / 1$ г почвы за 1мин, $\mathrm{AUB}-0.42, \mathrm{BM}-0.20$, $\mathrm{BMC}-0.40 \mathrm{~cm}^{3} \mathrm{O}_{2} / 1$ г почвы за 1мин соответственно.

Палинологические данные, полученные Б. Ф. Пшеничниковым, М. С. Лящевской, Н. Ф. Пшеничниковой (2018), показали, что нижняя часть метаморфического горизонта ВМ полигенетичных буроземов окрестностей бухты Спасения формировалась в условиях более теплого климата, чем современный. Это вполне сочетается с тем фактом, что в обоих исследованных нами разрезах наибольшие значения степени гумификации в профиле почв отмечаются примерно на одной глубине, в горизонте [AY] (38-66 см) в темногумусовой почве, сформированной на погребенном буроземе, и горизонте ВМ (39-56 см) в буроземе темногумусовом. Таким образом, морфологический облик и параметры гумусового состояния исследованных почв подтверждают полученные ранее сведения об изменении климата и уровня океана в юго-западной части тихоокеанского побережья региона.

\section{ВЫВОДЫ}

1. Бурозему темногумусовому и темногумусовой почве, сформированной на погребенном буроземе, свойственно среднее содержание гумуса, постепенно убывающее по профилю, и высокие запасы гумуса в поверхностном 20 -сантиметровом слое. Типовой состав гумуса по профилю исследованных почв значительно отличался. В буроземе темногумусовом с глубиной он меняется от фульватно-гуматного в поверхностном слое на гуматно-фульватный в середине профиля и фульватный в глубоких слоях. В полигенетичном профиле темногумусовой почвы, сформированной на погребенном буроземе, изменения типового состава гумуса от фульватногуматного в горизонте AU на фульватный в AUC и от гуматного в погребенном горизонте $[\mathrm{AY}]$ на гуматно-фульватный в [BM] могут свидетельствовать о различиях в климатических условиях формирования почв.

2. В составе гумуса обоих типов почв среди гуминовых кислот доминируют «свободные» фракции. Их доля среди ГК достигает высоких и очень высоких значений. При этом в поверхностных горизонтах бурозема темногумусового содержание ГК, прочно связанных с минеральной основой почв, выше, чем в темногумусовой почве, сформированной на погребенном буроземе.

3. Исследуемым почвам свойственна бедная и очень бедная обогащенность каталазой, что, вероятно, обусловлено слабой активностью почвенной микрофлоры.

4. Морфологический облик профиля и параметры гумусового состояния темногумусовой почвы, сформированной на погребенном буроземе, и бурозема темногумусового Дальневосточного морского заповедника подтверждают полученные ранее сведения об изменении климата и трансгрессии океана в юго-западной части тихоокеанского побережья региона в голоцене.

\section{ЛИТЕРАТУРА}

Агрохимические методы исследования почв. Москва : Наука, 1975. 656 с.

Белянин П. С. Ландшафты острова Фуругельма и их эволюция в позднем голоцене // Биота и среда заповедников Дальнего Востока. 2015. № 4. С. 88-101.

Гарковик A. B. Археологические памятники островов и побережья // Дальневосточный морской биосферный заповедник. Исследования. Владивосток : Дальнаука, 2004. Т. 1. С. 73-81.

Дергачева М. И. Органическое вещество почв: статика и динамика (на примере Западной Сибири). Новосибирск : Наука, 1984. 152 с.

Дергачева М. И. Гумусовая память почв // Память почв : Почва как память биосферно-геосферноантропосферных взаимодействий. Москва : Изд-во ЛКИ, 2008. С. 530-560. 
Дергачева М. И. Система гумусовых веществ как основа диагностики палеопочв и реконструкции палеоприродной среды. Новосибирск : Изд-во Сибир. отд-ния РАН, 2018. 292 с.

Добровольский В. В. О геохимической специфике почвообразования на морских и океанических островах и побережье // Почвоведение. 1991. № 4. С. 89102.

Добровольский Г. В., Урусевская И. С. География почв. Москва : Изд-во МГУ, Изд-во «КолосС», 2004. $460 \mathrm{c}$.

Елпатьевский П. В. Особенности почвенного покрова острова Фуругельма // Дальневосточный морской биосферный заповедник. Исследования. Владивосток : Дальнаука, 2004. Т. 1. С. 284-293.

Жарикова Е.А. Почвы южной части Дальневосточного морского биосферного заповедника // Почвы и ноосфера. Владивосток : Изд-во Дальневост. федерал. ун-та, 2019. С. 68-82.

Звягинцев Д. Г. Биологическая активность почв и шкалы для оценки некоторых ее показателей // Почвоведение. 1978. № 6. С. 48-54.

Зонн С. В. Особенности аллитного выветривания и почвообразования на островах Приморья и Дальнего Востока // Изучение и освоение природной среды. Москва : Ин-т географии АН СССР, 1976. С. 123-137.

Ивлев А. М. Географические закономерности формирования почвенного покрова в зоне перехода от Азиатского континента к Тихому океану // Материалы XIV Тихоокеан. науч. конгресса. Владивосток : ДВНЦ АН CCCP, 1982. C. 19-26.

Коваль Т. Г. Качественный состав гумуса почв острова Фуругельма // Генезис, химия и биология почв Приморья и Приамурья. Владивосток : ДВО АН СССР, 1987. С. 158-164.

Короткий A. М. Колебания уровня Японского моря и ландшафты прибрежной зоны (этапы развития и тенденции) // Вестник ДВО РАН. 1994. № 3. C. $29-43$.

Короткий А. М., Белянина Н. И., Гребенникова Т. А., Караулова Н. П., Иванова Е.Д., Мохова Л. М., Царько Е. И. Позднечетвертичные морские отложения в прибрежной зоне залива Петра Великого (Японское море) // Тихоокеанская геология. 2005. № 3. С. 32-48.

Костенков Н. М., Жарикова Е. А. Почвы прибрежной территории юго-западной части Приморья // Почвоведение. 2018. № 2. С.141-154. DOI: $10.7868 / \mathrm{S} 0032180 \mathrm{X} 18020028$.

Костенков Н. М., Кльшиевская С. В. Влияние процесса импульверизации на содержание солей в почвах прибрежных морских ландшафтов // Вестник Красноярского ГАУ. 2014. № 10. С. 81-84.

Ластовецкий Е. И., Якунин Л. П. Гидрометеорологическая характеристика Дальневосточного государственного морского заповедника // Цветковые растения островов Дальневосточного морского заповедника. Владивосток : ДВНЦ АН СССР, 1981. С. 18-33.

Латышева Л. А. Влияние пирогенной трансформации растительности на содержание и состав гумуса в буроземах островных территорий юга Приморья // Геосистемы Северо-Восточной Азии: осо- бенности их пространственно-временных структур, районирование территории и акватории. Владивосток : ФГБУН Тихоокеанский институт географии ДВО РАН, 2019. С. 247-252.

Meтоды почвенной микробиологии и биохимии. Москва : Изд-во МГУ, 1991. 303 с.

Научно-прикладной справочник по климату СССР. Сер. 3. Многолетние данные. Приморский край. Ленинград : Гидрометеоиздат, 1988. Ч. 1-6. Вып. 26. 416 с.

Орлов Д. С., Гришина Л. А. Практикум по химии гумуса : учеб. пособие. Москва : Изд-во Моск. ун-та, $1981.272 \mathrm{c}$.

Орлов Д. С., Бирюкова О. Н., Розанова М. С. Дополнительные показатели гумусного состояния почв и их генетических горизонтов // Почвоведение. 2004. № 8. С. 918-926.

Полевой определитель почв России. Москва : Почвенный ин-т им. В. В. Докучаева, 2008. 182 с.

Пшеничников Б. Ф., Пшеничникова Н. Ф. Генезис и эволюция приокеанических буроземов (на примере япономорского побережья). Владивосток : Изд-во Дальневост. ун-та, 2002. 292 с.

Птеничников Б. Ф., Птеничникова Н. Ф. Геохимическое воздействие Тихого океана на почвы юга Дальнего Востока // Почвоведение: история, социология, методология. Москва : Наука, 2005. С. 291-295.

Пшеничников Б. Ф., Пшеничникова Н. Ф. Буроземы архипелага Римского-Корсакова // Биота и среда заповедников Дальнего Востока. 2014. № 2. С. 123 143.

Пшеничников Б. Ф., Пшеничникова Н. Ф. Влияние растительности на гумусообразование и морфологическое строение приокеанических буроземов юговосточной части Приморья // Почвоведение. 2015. № 4. C. 387-396. DOI: 10.7868/S0032180X15040085

Пшеничников Б. Ф., Пшеничникова Н.Ф. Морфогенетическое разнообразие и классификация приокеанических буроземов юга Дальнего Востока России // Почвы и ноосфера. Владивосток : Изд-во Дальневост. федерал. ун-та, 2019. С. 57-67.

Пшеничников Б. Ф., Лящзевская М. С., Пшеничникова Н. Ф. Полигенетичные буроземы как отражение пространственно-временной динамики ландшафтов прибрежно-островной зоны залива Петра Великого (Японское море, Россия) // Ландшафтная география в XXI веке. Симферополь : Изд-во Типография «Ариал», 2018. С. 57-59.

Турсина Т. В. Подходы к изучению литологической однородности профиля и полигенетичности почв // Почвоведение. 2012. № 5. С. 530-546.

Хазиев $Ф . X$. Методы почвенной энзимологии. Москва : Наука, 2005. 252 с.

Чубарь E. А. Итоги инвентаризации флоры островов Дальневосточного государственного морского заповедника // Ботан. журнал. 2005. № 3. С. 360-367.

Schonbaum G. R. Catalase// The Enzymes. New York : Academic Press, 1976. 276 p.

Yang L., Li T., Li F., Lemcoff J. H.,Cohen S. Fertilization regulates soil enzymatic activity and fertility dynamics in a cucumber field // Scientia Horticul-turae. 2008. Vol. 116, No. 1. P. 21-26. 


\title{
ON ASSESSING THE HUMUS STATE AND ENZYMATIC ACTIVITY OF SOILS IN THE FAR EASTERN MARINE RESERVE
}

\author{
E. A. Zharikova, L. N. Purtova, A. D. Popova \\ Federal Scientific Center of the East Asia Terrestrial Biodiversity, FEB RAS, Vladivostok
}

\begin{abstract}
Indicators of humus state and catalase activity were determined in the soils of the Far Eastern marine reserve. The average humus content was exposed for the dark humus burozem and the dark humus soil, formed on buried burozem. The distribution of humus in the profile is estimated as gradually decreasing, the humus reserves in the $20 \mathrm{~cm}$ layer are characterized as very high and high. Variation of the typical humus composition and humification index differs in the studied soils. "Free" fractions predominate in the composition of humic acids, their proportion reaching high and very high values. The surface horizons of soils are characterized by poor and very poor catalase enrichment. The morphological shape of the profile and the parameters of the humus state of the studied soils of the far Eastern marine reserve confirm the previously obtained data on climate changes and ocean transgression in the South-Western part of the Pacific coast of the region in the Holocene.
\end{abstract}

Keywords: soils, humus status, catalase activity, climatic changes.

\section{REFERENCES}

Agrochemical Methods of Soil Study, 1975. Moscow, Nauka [In Russian].

Belianin, P. S., 2015. Landscape Structure of the Furugelm Island and Its Evolution in the Late Holocene, Biodiversity and Environment of Far East Reserves. 4, 88-101 [In Russian].

Dergacheva, M. I., 1984. Soil Organic Matter: Statics and Dynamics (on the Example of Western Siberia), Novosibirsk, Nauka [In Russian].

Dergacheva, M. I., 2008. Humus Memory of Soil, Soil Memory: Soil as a Memory of Biosphere-GeosphereAnthroposphere Interactions. Moscow, LKI Publishers, 530-560 [In Russian].

Dergacheva, M. I., 2018. System of Humus Substances as a Basis for the Diagnosis of Paleosurface and Reconstruction of the Paleoproduct Environment, Novosibirsk, SB RAN [In Russian].

Dobrovolskiy, G. V., Urusevskaya, I. S., 2004. Soil Geography. Moscow, Moscow State University [In Russian].

Dobrovolskiy, V.V., 1991. GeochemicalCharacteristics of Soil Formation on Sea and Ocean Islands and Shorelines, Soviet Soil Science. 23, 25-37.

Field Guide for Soils of Russia, 2008. Moscow, V. V. Dokuchaeva Soil Science Institute [In Russian].

Garkovik, A.V., 2004. Archaeological Monuments of the Islands and the Coast, Far Eastern Marine Biosphere Reserve. 1.Research. Vladivostok, Dalnauka, 73-81 [In Russian].

Ivlev, A. M., 1982. Geographical Regularities of the Formation of Soil Cover in the Zone of Transition from Asian Continent to the Pacific Ocean, Materials of the $14^{\text {th }}$ Pacific Scientific Congress. Vladivostok, FESC of the USSR Academy of Sciences, 19-26 [In Russian].

Khaziev, F. H., 2005. Methods of Soil Enzymology. Moscow, Nauka [In Russian].

Korotky, A. M., 1994. Fluctuations of the Sea of Japan Level and Landscapes of the Coastal Zone (Development
Stages and Tendencies), Vestnik FEB RAS. 3, 29-43 [In Russian].

Korotky, A. M., Belyanina, N. I., Grebennikova, T. A., Karaulova, L. P., Ivanova, E. D., Mokhova, L. M., Tsarko, E. I., 2005. Late Quaternary Marine Deposits in the Coastal Zone of Peter the Great Bay (Japan Sea), Russian Journal or Pacific Geology. 3, 32-48 [In Russian].

Kostenkov, N. M., Klyshevskaya, S. V., 2014. Effect of the Impulverization on the Content of Salts in Soils of Coastal Marine Landscapes, Bulletin of KrasGAU. 10, 81-84 [In Russian].

Kostenkov, N. M., Zharikova, E. A., 2018. Coastal Soils in the South-West of Primorye, Eurasian Soil Science. 51, 2, 140-152. DOI: 10.1134/S1064229318020059

Koval, T. G., 1987. Qualitative Composition of Humus of Furugelma Island Soils, Genesis, Chemistry and Biology of Primorye and Priamurye Soils. Vladivostok, FESC of the USSR Academy of Sciences, 158-164 [In Russian].

Lastovetsky, E. I., Yakunin, L. P., 1981. Hydrometeorological Characteristics of the Far Eastern State Marine Reserve, Flower Plants of the Islands of the Far Eastern Marine Reserve. Vladivostok, FESC of the USSR Academy of Sciences, 18-33 [In Russian].

Latysheva, L. A., 2019. Impact of Forest Vegetation Pyrogenic Transformation on Humus Content and Composition in Burozems of Island Territories in the Soutern Primorey, Geosystems of North-East Asia: Features of Their Spatial and Temporal Structures, Lend and Water Zoning. Vladivostok, PGI FEB RAS, 247-252 [In Russian].

Methods of Soil Microbiology and Biochemistry, 1991. Moscow, Moscow State University [In Russian].

Orlov, D. S., Biryukova, O. N., Rozanova, M. S., 2004. Additional Parameters of the Humus Status of Soils and of Their Genetic Horizons, Eurasian Soil Science. 37, 8, 798-805. 
Orlov, D. S.; Grishina, L. A., 1981. Practice in Humus Chemistry. Moscow, Moscow State University [In Russian].

Pshenichnikov, B. F., Pshenichnikova, N. F., 2002. Genesis and Evolution of Admarine Burozems (Exemplified by the Coast of the Sea of Japan). Vladivostok, FESU [In Russian].

Pshenichnikov, B. F., Pshenichnikova, N. F., 2005. Geochemical Effect of the Pacific Ocean on Soils in the South of the Far East, Soil Science: History, Sociology, Methodology. Moscow, Nauka, 291-295 [In Russian]. Pshenichnikov, B. F., Pshenichnikova, N. F., 2014. Burozems of the Rimsky-Korsakov Archipelago, Biodiversity and Environment of Far East Reserves. 2, 123-143 [In Russian].

Pshenichnikov, B. F., Pshenichnikova, N. F., 2015. The Impact of Vegetation on Humus Formation and Morphology of Brown Forest Soils in Coastal Areas of the Southeastern Part of Russia's Far East, Eurasian Soil Science. 48, 337-346. DOI: 10.1134/S1064229315040080 Pshenichnikov, B. F., Lyshevskay, M. S., Pshenichnikova, N. F., 2018. Poygenic Burozemz as a Reflection of Landscape Space-Time Dynamics in the Coast and Island Zone of Peter the Great Gulf (Sea of Japan, Russia), Landscape Geography in XXI Century. Simferopol, “Arial”, 57-59 [In Russian].

Pshenichnikov, B. F., Pshenichnikova, N. F., 2019. Morphogenetic Diversity and Classification of Admarine Burozems the Southern Far East of Russia, Soils and Noosphere. Vladivoctok, FEFU, 57-67 [In Russian].
Reference Book on Climate in the Soviet Union, 1988. Ser. 3 : Long-Term Data. Primorsky Kray. Leningrad, Gidrometeoizdat, 1-6, 26 [In Russian].

Schonbaum, G. R., 1976. Catalase, The Enzymes. New York : Academic Press.

Tchubar, E. A., 2005. Results of the Flora Inventory on the Islands in the Far East State Marine Reserve, Botanicheskii Zhurnal. 90, 3, 360-367 [In Russian].

Tursina, T. V., 2012. Approaches to the Study of the Llithological Homogeneity of Soil Profiles and Soil Polygenesis, Eurasian Soil Science. 45, 5, 472-487.

Yang, L., Li, T., Li, F., Lemcoff, J. H., Cohen, S., 2008. Fertilization Regulates Soil Enzymatic Activity and Fertility Dynamics in a Cucumber Field, Scientia Horticul-Turae. 116, 1, 21-26.

Yelpatyevsky, P. V., 2004. Features of the Soil Cover of Furugelma Island, Far Eastern Marine Biosphere Reserve. 1. Research. Vladivostok, Dalnauka, 284-293 [In Russian].

Zharikova, E. A., 2019. Soils of the Southern Part of the far Eastern Marine Biosphere Reserve, Soils and Noosphere. Vladivostok, FEFU, 68-82 [In Russian].

Zonn, S. V., 1976. Peculiarities of Allitic Wind Erosion and Soil Formation on the Islands of Primorye and Far East, Analysis and Exploration of Nature. Moscow [In Russian].

Zvyagintzev, D. G., 1978. Biological Activity of Soils and Some Scales for Its Evaluation, Soviet Soil Science. 6, 48-54 [In Russian]. 